A Journal of Culture, English Language, Teaching \& Literature

ISSN $1414-3320$ (Print), ISSN 2502-4914 (Online)

Vol. 17 No. 2; December 2017

Copyright ( () Soegijapranata Catholic University, Indonesia

Interactional Metadiscourse Markers in the Introduction of Dissertations: Differences across English Proficiency Level

${ }^{1}$ Yunik Susanti, ${ }^{2}$ Fabiola D. Kurnia, and ${ }^{3}$ Suharsono

${ }^{1,2,3}$ English Department, Faculty of Language Education and Literature, State University of Surabaya, Surabaya, Indonesia

email: 1yuniksusanti@unpkediri.ac.id,_fabiolakurnia@gmail.com, 3suharsono@unesa.ac.id

Received: 11-09-2017 Accepted: 13-11-2017 Published: 07-12-2017 


\title{
Interactional Metadiscourse Markers in the Introduction of Dissertations: Differences across English Proficiency Level
}

\author{
${ }^{1}$ Yunik Susanti, ${ }^{2}$ Fabiola D. Kurnia, and ${ }^{3}$ Suharsono \\ 1yuniksusanti@unpkediri.ac.id, ²fabiolakurnia@gmail.com, \\ 3suharsono@unesa.ac.id \\ ${ }^{1,2,3}$ English Department, Faculty of Language Education and \\ Literature, State University of Surabaya, Surabaya, Indonesia
}

\begin{abstract}
Following the interactional concept of Metadiscourse by Hyland and Tse (2004) then developed by Hyland (2005), this content analysis aims to find the use of interactional categories of metadiscourse in the introduction sections of two dissertations written by more and less proficient writers graduated from doctorate program. The interactional metadiscourse markers were categorized into booster, hedges, attitude markers, engagement markers, and self-mention. The results of analysis showed that the more proficient writer used more in number and variations of interactional metadiscourse markers than those of the less proficient writer did. For the most frequent interactional metadiscourse markers, the more proficient writer used engagement marker, while the less one used self-mention as the most frequent marker in introducing the study and reviewing related research. It means that the more proficient a writer, the more number and variations of interactionaal metadiscourse to be used. Then the writers tend to include the readers and show their presence more in presenting the arguments without being so assertive. It is suggested for the English teacher/lecturer to teach explicitly the use of interactional metadiscourse especially in the aspect that can show the writers' presence in presenting their arguments on their research reports.
\end{abstract}

Key words: interactional metadiscourse markers, introduction section, dissertation

Abstrak: Mengikuti konsep tentang model Interpersonal dari penanda Metadiscourse yang telah dikemukakan oleh Hyland dan Tse (2004) 
Susanti, Y., Kurnia, F.D., \& Suharsono, Interactional Metadiscourse Markers 271 in the Introduction of Dissertations: Differences across English Proficiency Level

yang kemudian dikembangkan oleh Hyland (2005), penelitian analisis isi ini bertujuan untuk menemukan penggunaan penanda metadiscourse Interaksional pada bab pendahuluan dari dua buah disertasi yang ditulis oleh penulis yang baik dan penulis yang kurang baik mahasiswa lulusan S-3 pascasarjana. Penanda-penanda metadiscourse tersebut dianalisa menurut lima kategori; "Booster", "Hedges", "Attitude Markers", "Engagement Markers", dan "Self Mention". Dari hasil analisa data ditemukan bahwa penulis yang baik menggunakan lebih banyak dan lebih bervariasi penanda-penanda metadiscourse interaksional dari pada penulis yang kurang baik. Untuk penanda interaksional yang paling sering digunakan fekwensinya, penulis yang baik menggunakan penanda "Engagement" dan penulis yang kurang baik menggunakan penanda "Self Mention". Jadi dapat disimpulkan bahwa semakin terampil penulis semakin banyak dan bervariasi penanda metadiscourse interaksional yang digunakan. Penulis cenderung melibatkan pembaca dan menunjukkan kehadiran mereka secara lebih dalam mempresentasikan pendapat mereka tanpa menggunakan katakata yang tegas.Jadi disarankan pada guru/dosen bahasa Inggris untuk mengajarkan secara ekplisit penggunaan penanda metadiscourse terutama dalam penggunaan yang dapat menunjukkan kehadiran mereka dalam mengemukakan pendapat merekan dalam penulisan karya tulis ilmiah.

Kata kunci: penanda metadiscourse interaksional, bab pendahuluan, disertasi

\section{INTRODUCTION}

The categories of metadiscourse markers has been developed by several researchers; Kopple (1985) categorized them into two broad categories; textual and interpersonal types. This classification were not clear and ambigious, so it was difficult to be applied in practice. Then it was developed and evaluated by Crismore, Markkanen, \& Steffensen (1993) and Hyland (1998). This research uses the recent and practical metadiscourse categories propossed by Hyland and Tse (2004) and then developed by Hyland (2005), called as an interpersonal model of metadiscourse. This type classifies metadiscourse into two categories such as; Interactive and Interactional metadiscourse markers. The interactive categories consists of; transititions, frame markers, endhophoric markers, endophoric markers, evidentials and code glosses. The interactional categories consists of; hedges, boosters, attitude markers, self mentions, and engagement markers (Hyland, 2005, p.49). 
Hyland and Tse (2004) stated that metadiscourse is interpersonal because it considers the reader's background knowledge, textual experiences, and the ability understand the content. It facilitates writers with aspects to achieve these functions. Although it is stated that all metadiscourse is interpersonal because of the relationship between the writer and the readers, Metadiscourse are categorized into two aspects: first, the organizational choices that are referred to the interactive resources, while the evaluative and engagement features that are referred to the interactional metadiscourse.

In this study the interpersonal model of metadiscourse classification is used to analyze the use of metadiscourse markers in academic writing. As we know that in academic writing, writers are hoped to be able to present their knowledge and show their proficiency with certain skills of thinking, interpreting, and presenting ideas. Those idea related to a specific discipline that have their own key concept and language for describing the important ways of understanding. Those key concept employed in each dicipline can be illuminated by the existence of metadiscourse. Nasiri (2013, p.72) explains the main roles of the metadiscourse markers in terms of academic writing; first, the use of metadiscourse markers can help the academic writers learn content better. By using the metadiscourse markers a writer can adjust the level of personality in his/her texts, to offer a representation of him/herself and him/herself arguments. These functions reveal writer's understand of the readers and their need for explanation, clarification and guidance.

Dissertation writing is a high achievement of writing that students' make at the end of their study in post graduate program, so the use of metadiscourse are varied in numbers and types. By having rich number and variation of metadiscourse in this section it is possible to get the example of metadiscourse for the purpose of this study. Hyland $(2004, \mathrm{p} .12)$ states that dissertation show the writer's ability to write in high standard of writing in the different language. Dissertation is an advanced level piece of academic writing produced by the students who considered in advanced English proficiency. In a high standard piece of writing the use of metadiscourse markers is in a greater number and variety. It is supported by the result of a research conducted by Gholami (2014) that revealled that the writer's language ability has a positive relationship with the uses of metadiscourse and the quality of their writing. By having greater number and variation of metadiscourse, it can be identified easily the example of the use of metadiscourse in its context of use. 
Susanti, Y., Kurnia, F.D., \& Suharsono, Interactional Metadiscourse Markers 273 in the Introduction of Dissertations: Differences across English Proficiency Level

Another research conducted by Intaraprawat and Steffensson (1995) stated that good writer showed a greater variety of metadiscourse markers than the poor one, then the skilled writers have an understanding of readers needs and control the way how to make their texts are easier to be read and understood by the readers. In addition, Hidayati, Muhammad, \& Dallyono (2008), who has investigated about the use of hedging (one of the five categories in Interactional metadiscourse markers), the students' ability to write appropriately, and the students' awareness toward the use of hedging in the theses written by English Department graduates students of Bandung Education University (UPI) Bandung, found that all types of hedging were used with some inappropriateness and the students' education level influences the awareness toward the use of hedging. The use of hedging and other metadiscourse markers in doctorate graduates is essential to be investigated because there would be potential variation in terms of the distribution and their reasons for using them in their works, resulting from their doctorate education background. So, the focus of analyzing the use of metadiscourse markers in theses or dissertation is still open to be discussed and it is also acts as the development of the previous research.

One of the consideration of conducting this research is as what Hyland (2005) suggested to the further researcher to conduct a research on the use of metadiscourse in another cultural academic as metadiscourse research can contribute to the important work conducted by Hinkel (2002), Mauren (1993) and others into intercultural discourse variation, exploring the expectation for particular metadiscourse form and interpersonal practices of different first language groups in the target contexts. In addition, Hyland (2005, p.250) also states that research into the ways metadiscourse is typically used by different discourse communities can help seeing more clearly about how texts are the result of interactions, and how discourse practices which involve engagement in a web of professional and social associations. By revealing the interactional and interactive preferences of writers in different communities, it can be learnt more not only about the approved rhetorical practices but also about the values, norms, understandings and institutional structures which they reflect. By revealing the ways interpersonal practices depend on discourse domain and context, metadiscourse research can help learners attend to features that are used differently in their own discourses. Finally, it can be stated that the focus of this research is an open discussing point due to the fact that there has been no other research taking this problem so it can develop the previous research. 
This study investigates the introduction section of the dissertations written by two writers, more and less proficient writers, graduated from English department of a Doctorate program. The importance of analyzing the introduction section of the dissertation is based on some considerations that can be explained as follows; firstly, it is a development of the previous research conducted by Letsoela (2013) who investigated the metadiscourse markers in National University of Lesotho Undergraduate Students' Academic Writing in discussion section only. He suggested to conducting further research in the use of metadiscourse markers in other sections of the research report on postgraduate students' writing so it will be found the similarity or the differences of the use of metadiscourse markers between undergraduate and graduate research report writing and also might reveal the interesting observations.

Furthermore, the reason of choosing the introduction section of the dissertation that is because this section is known to be rich context for metadiscourse features. Swetnam (2004, p.74-75) states that the introduction section functions to explain thinking, break the ice, establish a style and provide a basis for a tutorial. It should explain in general, what the purpose of the research: whether it searches for new knowledge, policy change or evaluation. Then it goes on to state concisely what it is intended to do, the research questions, and the location of the research. It is scholarly in style, clear and direct in style with several references, general texts that deal with the basic theories. So it is important to write a coherent and acceptable text, with several quotations from sources to help establishing the right tone. All of those aspects can be illuminated by the use of metadiscourse especially in the use of the interactional categories that consists of hedges, booster, attitude markers, self-mention and engagement markers. The use of interactional metadiscourse can make the writer engage with their reader as participants in the ongoing discussion.

\section{LITERATURE REVIEW}

It is not easy to categorize and to identify the metadiscourse markers. Hyland (2005) states that metadiscourse can be seen as open category to which writers are able to add new items according to the needs of the context. The focus of metadiscourse studies is on explicit textual device items which can be identified in the text. There are two realizations of the devices, called as metadiscourse markers, first non-verbal signals and the other is 
Susanti, Y., Kurnia, F.D., \& Suharsono, Interactional Metadiscourse Markers 275 in the Introduction of Dissertations: Differences across English Proficiency Level

verbal signals. Crismore et al. (1993, p. 48; see Hyland, 2005, p. 28) categorized nonverbal metadiscourse markers into two broad aspects; oral and written aspects. In oral nonverbal metadiscourse, the examples of metadiscourse markers are paralinguistic aspect which accompany spoken messages, such as; tone of voice and stress, proximity such as physical distance, and kinesics such as gesture, and facial expression. In written texts, various forms of punctuation and typographical marks such as; underline, capitalization, exclamation marks, etc.

This research focuses on verbal metadiscourse markers as it analysis the words or phrases functioned as metadiscourse in the students' dissertation writing. In the verbal potential metadiscourse markers, there are a number of different ways which these features have been categorized as the breadth of meaning realized by these markers. Most taxonomy are closely based on that proposed by Koople (1985), whose categorization consists of seven kinds of metadiscourse markers that are divided into textual and interpersonal types. The textual metadiscourse consists of text connectives, code glossess, validity markers, and narrators. The interpersonal metadiscourse consists of illocution markers, attitude markers, and commentaries.

Some researchers have used these classifications, such as Crismore and Farnworth (1989, 1990) Intaraprawat and Steffensen (1995), then Cheng and Steffensen (1996). The terminology and these functional categories are based on Systemic Functional Grammar's textual and interpersonal metafunctions of language as explained by Halliday (1973). Thus, the text organizing and interpretive aspects of metadiscourse are labelled textual metadiscourse while the evaluative, attitudinal and engagement aspects are labelled as interpersonal metadiscourse.

Thus, other researchers, Hyland and Tse (2004) stated that metadiscourse is interpersonal. It is called as interpersonal because it consider the reader's needs, textual ability, and processing needs. It suggests writers with many rhetorical choices to reach the functions. So, the last theory which devided metadiscourse into textual and interpersonal types is not relevance anymore. Because all metadiscourse is interpersonal because there is continous dialogue between the writer and the reader. In the interpersonal theory of metadiscourse, metadiscourse are divided into interactive and interactional metadiscourse.. The organizational aspects are referred to as interactive metadiscourse while the evaluative and engagement features are referred to as interactional metadiscourse. 
In writing dissertation, the writers are hoped to be able to provide contribution of knowledge through their research. It is more than just reporting the previous research, but they are hoped to analyze and to take a side, state their arguments by challenging the existing arguments, idea and theories. In addition, in writing the dissertation, there are some chapter and sub-chapter that must be written in clear and brief structure (Wallace and Wray, 2009). According to Swetnam (2004, pp. 46-47) a typical dissertation has between five or eight chapter such as introduction, literature review, research methodology, data analysis, conclusion, bibliography, and appendixes, they can be explained as follows: the first chapter is introduction.

The introduction sets the scene. It introduces the question/problem and explains the purpose and focus of the paper. It also provides some background information, for instance on previous work in the area, and on research gaps. If necessary, it provides definitions of the key term(s). Finally, the Introduction outlines in summary form how the writers are going to deal with the topic, and the various stages that will be taken before reaching the conclusion. If it is needed it is also possible to state here why the topic is relevant, for instance in relation to the writers' professional context. In short, the 'introduction chapter presents the (1) background and (2) the aim and objectives of the study, i.e. the relevance of topic; the reasons for the writer interest in it, and (briefly, because this will be dealt with in more detail in the Literature Review) the current knowledge of the topic. The writers may 'frame' their own research here, stating that is a need for doing that research to fill knowledge gaps. At this point, the writers may want to point out what the research is going to contribute to existing knowledge. Leading on from (1) and (2), the writers may state the (3) research questions. Next, provide an (4) Outline of the dissertation with a brief overview of the following chapters. In short it can be said that the introduction chapter should answer the following questions: What is going to be done? Why is it to be done? Who is likely to be interested in it? What exatcly is the hypothesis or problem? What is the possible use of the research? What is the locus and focus? (Swetnam, 2004, pp. 46-47).

Some researchers have conducted studies about metadiscourse markers. The following are the review of those researches;

Intaraprawat and Steffensen (1995) conducted a research entitled "The Use of Metadiscourse Markers in good and poor ESL Essays", they found that good essays showed a greater variety of metadiscourse markers within 
Susanti, Y., Kurnia, F.D., \& Suharsono, Interactional Metadiscourse Markers 277 in the Introduction of Dissertations: Differences across English Proficiency Level

each categories than the poor essays. They also stated that skilled writers have an awareness of the needs of their readers and control the strategies for making their texts more considerate and accessible to the readers. On the contrary, poor writers are not able to generate considerate texts. In more advanced writers, Hyland (2004) conducted his research in the post graduate level entitled "Disciplinary Interaction: Metadoscourse in L2 Postgraduate Writing". He found that the use of metadiscourse markers vary across the master and doctorate writers and also vary across the disciplinary communities. The doctorate writers used more metadiscourse markers than those the master's writers. In the disciplinary communities, the more 'soft knowledge" / social science disciplines, the more metadiscourse markers used.

In investigating further about the use of the interactional metadiscourse markers, hedging and boosters, in research article, Salichah, Irawati, \& Basthomi (2015) conducted a research entitled "Hedges and Boosters in Undergraduate Students' Research Article”. They found that there were five types of hedges used and three types of boosters in the articles. However, the students overused and misused hedging devices of 'can', as 'can' is the most familiar hedge typically taught to and digested by Indonesian EFL learners. In using the boosters, the students overstated and exaggerated in the use of universal pronoun. Furthermore, in investigating the use of Hedges and Booster in English Academic Articles, Takimoto in his research "A Corpus-Based Analysis of Hedges and Booster in English Academic Articles" (2015) found that hedges exceed booster, and the natural sciences were underrepresented in the number of hedges and booster. It was also found that choices the writers made were influenced by the discourse norms and rhetorical styles of each discipline and reflect the nature of different disciplinary characteristics.

\section{METHODS}

The data of this study are words or phrase functioned as interactional metadiscourse in introduction of two dissertations written by more and less proficient writers of post-graduate students. In this study, the variety under investigation refers to the three categories of graduation such as; cum-laude, very satisfying and satisfying categories. Those categories are determined based on the Grade Point Average (GPA). The range of GPA categories for doctorate students are as follows; first; GPA 3.81- 4.00 is cum laude, if the 
study can be finished in or before 4 years, then GPA3.51 -3.80 is very satisfying, and the last is, GPA of $3.00-3.50$ is satisfying. From all of the population, there are 3 writers who got Cum Laude, then there are 22 writers with very satisfying categories and there are 3 writers with satisfying one. This research selects one (1) dissertation from cum laude and satisfying categories, so in total there are two (2) introduction section from two dissertations becomes the sample of this research. The chosen sample from each category such as: the dissertation written by cum laude category writer with GPA 3.88 in a 3-year study duration, and the dissertation written by satisfying category writer with GPA 3.26 in a 7-year study duration.

In this content analysis the research becomes human instrumentation, as she collects, analyses and interprets the data. Here, the introduction sections of the dissertation are carefully read word by word with specific attention to the function and meaning of the words functioned as metadiscourse. In identifying and locating the interactional metadiscourse, this study uses the most recent taxonomy of metadiscourse markers by Hyland (2005). The interpretation depends on the human judgment to determine the function of the expressions in the contexts of use.

The next instrument is documentation, in the documentation process, a coding scheme, which is developed based on Hyland's (2005) potential metadiscourse markers list, is used. This model is used because it is recent, simple, clear, and comprehensive categories. The list about three hundred (400) lexical items are used for the mater of analysis. Then the manual frequency count is used to have a record of the specified interactional metadiscourse in the examined dissertations. As the size of the introduction section these two dissertations is unequal across the different GPA categories and to make the length of the text consistent, it is decided to calculate the frequency of metadiscourse markers per three thousand (3000) words as the shortest length of the introduction srction of the two dissertations is 3000 words.

After determining the type of interactional metadiscourse employed in introduction sections of the dissertations sample, the collected data are counted their frequency then analyze using frequency formula. Then the word or phrase functioned as interactional metadiscourse is described qualitatively in order to explain the variation of the words or phrases functioned as interactional metadiscourse in the introduction section of the dissertation writing. 
Susanti, Y., Kurnia, F.D., \& Suharsono, Interactional Metadiscourse Markers 279 in the Introduction of Dissertations: Differences across English Proficiency Level

\section{FINDINGS AND DISCUSSION}

Interactional metadiscourse markers are used to show the writer's position about the presented information and also to engage the readers as the participants of the dialogue process of using the language. By using these markers, the writer tries to involve the reader to the communication process. The following are the data about the use of the interactional metadiscourse markers in the introduction section used by the more proficient writer.

\section{A. The use of interactional metadiscourse markers in the introduction section dissertations written by more proficient writers}

In the introduction section, there are some items used by a good writer that can be categorized as Interactional Metadiscourse markers. The following are the data about the use of the interactional metadiscourse markers:

\section{1. $\underline{\text { Boosters }}$}

Boosters are words that facilitate writers to close alternatives, face conflicting views, and express their certainty in what they say. They emphasize certainty or close dialogue. In the introduction section, the booster markers are used four times. The following are three examples and the analysis of the use of those markers:

a) These qualities of existentialism are clearly seen in the life story of Orhan Pamuk and in his ways of life.

b) Undoubtedly, it has also made him a great fortune in his writing career. During an interview after winning the International Dublin Literary Award.

c) Both novels have indeed explored a great number of the major themes in the philosophy of existentialism.

In the first example the word "clearly" functions as booster as it indicates the writer's certainty about the existence of the existentialism in the author that he chose as the object of the study. In the second sentence again the writer was very confident toward his opinion by using the word "undoubtedly". $\mathrm{He}$ hopes that the readers have the same opinion as his. Furthermore, in the last example, the word "indeed" also emphasizes the good writer certainty about his argument. 
280 Celt: A Journal of Culture, English Language Teaching \& Literature, Volume 17, Number 2, December 2017, pp. 270 - 291

\section{Hedges}

Hedges are tools used by the writer to decide the point of view and complete commitment to a proposition. They express commitment and open dialogue. The hedges markers are used eleven times in the introduction. The following are the three data on the use of the markers:

a) He claimed that human beings first exist with nothingness and only after they exist that some essence may develop.

b) A novel may have one or more philosophical schools of thought along its story, depending on the intentions of its author.

c) The theme, characters and plots of a novel, for instance, may actually represent its author's philosophical views of life and even his own personal life experiences.

In the first sentence, the word "claimed" is categorized as hedges because it expresses the writer point of view about the existence of the time certain essence of life developed. In the second sentence, the word "may" function as interactional metadiscourse markers as it implies the writer opinion about his doubt whether or not a novel contains a philosophical thought. Finally, the third sentence the word "may" also expresses the writer opinion rather than fact whether the theme, character and plots of a novel reflected the author's philosophical idea and personal life or not.

\section{Attitude markers}

Attitude markers indicate the writer's affective and attitude to propositions. Attitude markers convey surprise, agreement, importance, obligation, and frustration. The attitude markers are used four times in the introduction. The following are the data on the use of the markers:

a) most popularly, Sartre $(1946, p .22)$ stated that man first of all exists, encounters himself, surges up in the world, and then defines himself afterwards. (importance)

b) and most importantly, the journey to discover the philosophy of life is beginning.

c) most importantly, he has exhibited the greatest virtues in him as a man who was once lost in the wilderness of uncertainty, emptiness, downfall and failure but then again and again he kept 
Susanti, Y., Kurnia, F.D., \& Suharsono, Interactional Metadiscourse Markers 281 in the Introduction of Dissertations: Differences across English Proficiency Level

trying to seek and find his true self until today he has created his own meanings to his life.

In those three examples, the phrase "Most popularly", "Most importantly" are used to express the writer attitude toward the main information. In those sentences the writer shows the agreement and the importance of the statements.

\section{Engagement markers}

Engagement Markers are devices used to address readers directly in order to get the reader attention or to include them as discourse participants, They explicitly, build a relationship with reader. The engagement marker is used nineteen times in the introduction section. The following is the sentence that contains the engagement marker:

a) Therefore, good literary works must have both beauty and utility. More than two thousand years ago, the Roman poet...."

b) Every person may at times feel the loss of self-identity during which we become uncertain of what to be and where to go to find the purposes and meanings of life.

c) We all construct our own ways of understanding

In the first example, the obligation modal "must" function as engagement markers because it functions directly to guide the readers to interpret the writer's idea as what the writer's want. In the second and third example, the words "we" and "our" (inclusive), function to include the readers in the discussion.

\section{Self-mention}

Self-mention refers to the level of explicit writer presence in the text. They explicitly refer to writers. The self-mention marker is used four times in the introduction section. The following are the example of the use of selfmention:

a) It is based on this standpoint that the researcher is interested in conducting a research to analyze and discover the thoughts of existentialism as one of the philosophies that attracts his most attention within Orhan Pamuk's novels, Snow and the Museum of Innocence. 
282 Celt: A Journal of Culture, English Language Teaching \& Literature, Volume 17, Number 2, December 2017, pp. 270 - 291

b) Another reason that the researcher has considered in choosing Orhan Pamuk for this study is the author's extraordinary achievement in his literary works.

In the above example the writer tries to explicitly express his presence by using the third singular person "the researcher". The function of the word "the researcher" in the first and second example is to explicitly express the existence of the writer.

From the data above it can be clearly counted that there are 42 items that can be categorized as interactional metadiscourse markers. All of the types of the interactional metadiscourse markers can be found in this section. So, in order to make it clearer, the use of each interactional metadiscourse markers can be seen in the following table:

Table 1:

Interactional metadiscourse markers in introduction section of more proficient writer (per-3000 words)

\begin{tabular}{lll}
\hline \multicolumn{1}{c}{ Category } & F & P \\
\hline Booster & 4 & 9.5 \\
\hline Hedges & 11 & 26 \\
\hline & & \\
\hline Attitude Markers & 4 & 9.5 \\
\hline Engagement Markers & 19 & 45.2 \\
\hline Self Mention & 4 & 9.5 \\
\hline Total & 42 & 100 \\
\hline
\end{tabular}

From the table above, we can figure out that that the most frequent number is Engagement markers, there are total of 19 items per 3000 words or $45.2 \%$. The high degree of Engagement markers means that the good writer tries to take the readers to be involved in the discourse as an active participant, in order to make their idea clearer. As Swetnam (2004, p.47) stated that in introduction the writers form their own research, state that is a need for doing that research to fill knowledge gaps. The writer may want to point out what the research is going to contribute to existing knowledge. So it is important to get the presentation of the information can be well presented and comprehended. It is followed by Hedges with the total of 11 items per 3000 words or $26 \%$, the next is Booster with the total of 4 items in 3000 words or $9.5 \%$. The number of hedges that was more than the number of booster indicates that the writer wanted to be more subjective and 
Susanti, Y., Kurnia, F.D., \& Suharsono, Interactional Metadiscourse Markers 283 in the Introduction of Dissertations: Differences across English Proficiency Level

interpretive, it is suitable as the characteristic of the social and humanities subject that is more subjective and interpretive (Takimoto, 2015). However, the good writer tries to be firm in stating the idea but at the same time considering that the readers will be at his superior position or at the same level, so he used hedges to soften it. The last two markers, Attitude Markers and Self-Mention have limited number there were only 4 or $9.4 \%$ for both Attitude Markers and Self Mention.

There are variations on the items used by the more proficient writer that has been categorized as interactional metadiscourse markers. The following table explains those items:

Table 2:

Items identified as interactional metadiscourse markers in introduction section of good writers

\begin{tabular}{lll}
\hline Category & F & P \\
\hline Booster & 4 & 9.5 \\
\hline Well known & 1 & \\
Indeed & 1 & \\
Clearly & 1 & \\
Undoubtedly & 1 & 26 \\
\hline Hedges & 11 & \\
Claimed & 1 & \\
Argued & 1 & \\
Can & 3 & 9.5 \\
May & 6 & \\
\hline Attitude Markers & 4 & 45.2 \\
Most importantly & 3 & \\
Most popularly & 1 & \\
\hline Engagement Markers & 19 & \\
Must & 1 & \\
We & 7 & \\
Our & 10 & 100 \\
Us & 1 & \\
\hline Self Mention & 4 & \\
The researcher & 4 & \\
\hline Total & 42 & \\
\hline
\end{tabular}

In this table, among the items categorized as interactional metadiscourse markers, the word "our" becomes the most frequent marker 
to be used, followed by the word "we" as the Engagement Marker category. The use of the possessive pronoun "our" and the first pronoun, plural personal pronoun "we" were used to make the readers participate in the discussion. By using these words, the good writer tries to take the readers to the discussion about the background knowledge of the research, so the idea that the current research gives an advanced knowledge toward the current one can be comprehended well. The word "May" becomes the next frequent items to be used as the hedging marker.

\section{B. The use of interactional metadiscourse markers in the introduction section of dissertations written by less proficient writers}

In introduction section, it can be found items used by the less proficient writer that can be categorized as Interactional Metadiscourse markers. The following are the data about the use of those interactional metadiscourse markers:

\section{Hedges}

Hedges are used to express the writer commitment and to open dialogue with the readers. Here, hedges markers are used eleven times in the introduction. The following are the data on the use of that marker:

a) Madurese should be learned by elementary school students as it is the potential source of culture

b) In general, the study is to evaluate the English teaching materials for the fourth grade elementary school in Bangkalan.

c) ....the materials in the book should be compatible with the curriculum.

In the first and third example the word "should" function as interactive metadiscourse markers because it let the reader to be active in the discussion about the importance of teaching Madurese in Elementary School and also about the importance of the materials in the book to be compatible with the curriculum.

\section{Engagement markers}

Engagement marker is used by the writer to explicitly build relationship with the readers. The Engagement marker is used four times in the introduction section. The following is the sentence that contains the engagement marker: 
Susanti, Y., Kurnia, F.D., \& Suharsono, Interactional Metadiscourse Markers 285 in the Introduction of Dissertations: Differences across English Proficiency Level

a) The main assumption underlying the teaching of English at elementary school seems to be related to the age of the learners

b) Student books as the supporting process must also be standardized.

c) ESB needs to be evaluated. This study is to evaluate the English teaching materials for the fourth grade elementary school in Bangkalan especially the English student book published by the BECS.

In the first example the word "seems" functions to invite the readers to discuss the matter of the teaching of English at Elementary school. In the second example the word "must" means the writer point of view about the standardized of the students' book, and in the last example again the writer opens a discussion with the readers about his opinion about the importance to do evaluation to the book.

\section{Self-mention}

Self-mention used by the writer to develop relationship with the readers by address the readers as the text participants. In the introduction section the poor writer used self-mention marker thirteen times. The following are the example of the use of the Self-mention:

a) The writer uses the national standard of evaluation which has certain criteria.

b) The writer pays attention to the teacher and the learners' activity.

c) From the content, the researcher evaluates the teaching materials in ESB and the compatibility of the materials with the competence standard and the basic competence in the 2006 English curriculum.

In the first sentence and second sentences, the phrase "the writer" used as Self-mention device, they function to take the readers into the discussion and treat the readers at the same position as the writer. In the third example, the phrase "the researcher" is used instead of "the writer".

From those data presented above, it can be clearly counted that there are 28 items that can be categorized as interactional metadiscourse markers. There were only three categories of interactional metadiscourse markers used 
286 Celt: A Journal of Culture, English Language Teaching \& Literature, Volume 17, Number 2, December 2017, pp. 270 - 291

by the less proficient writer, the two categories, Booster and Attitude Markers, were not used. It means that the less proficient writer did not use all of the categories of the interactional metadiscourse markers.

So, in order to make it clearer, the use of each interactional metadiscourse markers can be seen in the following table:

Table 3:

Interactional metadiscourse markers in introduction section of less proficient writer (per-3000 words)

\begin{tabular}{llll}
\hline \multicolumn{1}{c}{ Category } & Number of Terms & Mean & \% of total \\
\hline Booster & 0 & 0 & 0 \\
\hline Hedges & 11 & 0.3 & 39.2 \\
\hline Attitude Markers & 0 & 0 & 0 \\
\hline $\begin{array}{l}\text { Engagement } \\
\text { Markers }\end{array}$ & 4 & 0.15 & 14.2 \\
\hline Self Mention & 13 & & \\
\hline Total & 28 & 0.5 & 46.4 \\
\hline
\end{tabular}

From the table above, it can be known that the most frequent number is Self -Mention, there were 13 items or $(46.4 \%)$. It is followed by Hedges with the total of 11 items per-3000 words or $39.2 \%$, the next is engagement markers with the total of 4 items in 3000 words or $14.2 \%$, then there were no Attitude Markers and Booster can be found. In order to make the description of the use of the interactional metadiscourse markers clearer, in the following data, the use of the items that categorized as interactional metadiscourse markers are presented. In table 4, which is about the words or phrase that can be categorized as interactional metadiscourse markers above, we can see that the word "should" is the most frequent word to be used as Hedges marker. It is followed by the word "the writer" as the interactional metadiscourse marker in Self-Mention marker.

Table 4:

Items identified as interactional metadiscourse markers in introduction section of less proficient writer (per-3000 words)

\begin{tabular}{llll}
\hline Category & F & & P \\
\hline Booster & 0 & 0 & \\
\hline
\end{tabular}


Susanti, Y., Kurnia, F.D., \& Suharsono, Interactional Metadiscourse Markers 287 in the Introduction of Dissertations: Differences across English Proficiency Level

\begin{tabular}{llll}
\hline Hedges & 11 & & 39.2 \\
Can & 2 & & \\
Should & 7 & & \\
In general & 2 & & 0 \\
\hline Attitude Markers & 0 & & $14.2 \%$ \\
\hline Engagement Markers & & & \\
seems & 4 & $46.4 \%$ \\
Must & 1 & \\
Need & 1 & \\
\hline Self Mention & 2 & \\
The writer & 13 & 100 \\
The researcher & 6 & \\
He & 4 & \\
\hline Totals & 3 & \\
\hline
\end{tabular}

This result showed that the writer avoided using first person pronoun because it is thought that using the first person make writing sound more objective, so the third person "the writer/the researcher/ he as the most common point of view in academic writing is used (Pope, 2011).

\section{Table 5:}

Interactional metadiscourse markers in introduction section of more and less proficient writer (per-3000 words)

\begin{tabular}{llll}
\hline \multicolumn{1}{c}{ Category } & \multicolumn{1}{c}{$\begin{array}{c}\text { Good } \\
\text { Writer }\end{array}$} & $\begin{array}{c}\text { Poor } \\
\text { Writer }\end{array}$ & Total Percentage \% \\
\hline Booster & 4 & 0 & 6 \\
\hline Hedges & 11 & 11 & 32 \\
\hline Attitude Markers & 4 & 0 & 6 \\
\hline Engagement Markers & 19 & 0 & 27 \\
\hline Self Mention & 4 & 13 & 24 \\
\hline Total & 42 & 28 & 100 \\
\hline \multicolumn{1}{c}{ From } & 5,
\end{tabular}

From table 5, we can notice that there are more interactional metadiscourse markers used by the more proficient writer. There were also more variations on the use of the interactional metadiscourse markers. This result supported the study conducted by Intaraprawat and Steffensen (1995) who found that good essays showed a greater variety of metadiscourse markers within each category than the poor essays.

They also stated that skilled writers have an awareness of the needs of their readers and control the strategies for making their texts more 
considerate and accessible to the readers. This result also supported the result of the research conducted by Simin and Tavangar (2009) who found that the more proficient learners are in second language, the more they use metadiscourse markers.

\section{CONCLUSION}

At this stage, we have discussed about the use of the interactional metadiscourse markers in introduction section of the dissertation written by two different writers who have different English Proficiency. Form the result of the research described above, it is obvious that the better writer the more interactional metadiscourse markers used.

In using those markers, the more skillful writer use more variation on the use of words and phrases functioned as Interactional Metadiscourse markers. As the sample of the more and less proficient writer in this research is limited in two dissertations, it is suggested for the future research to conduct a research in the research report written by more writers in the broader universities in Indonesia and in all section of the dissertation, so the more comprehensive data will be reached. Furthermore, in order to get more complete data, it is suggested to use not only documentation but also interview and SRM (Stimulated Recall Methodology).

By using these instruments, the respondent point of view will be able to collect. It is also found that the less proficient writer uses less interactional markers both in number and variation, so it is suggested for the lecturer/ teacher to introduce and give explicit practice to the students about the use of interactional metadiscourse markers.

\section{ACKNOWLEDGEMENTS}

Parts of this paper have been presented at the $5^{\text {th }}$ Celt International Conference in Semarang, Indonesia during 9-11 ${ }^{\text {th }}$ September 2017. The conference was a project funded by the Ministry of Research, Technology, and Higher Education. 
Susanti, Y., Kurnia, F.D., \& Suharsono, Interactional Metadiscourse Markers 289 in the Introduction of Dissertations: Differences across English Proficiency Level

\section{REFERENCES}

Crismore, A. \& Farnsworth, R. (1989). Metadiscourse in popular and professional science discourse. In W. Nash (Ed), The writing scholar: Studies in academic discourse. Newbury Park, C.A: Sage.

Anwardeen, N. H., Luyee, E. O., Gabriel, J. I., \& Kalajahi, S. A. R. (2013). An analysis: The usage of metadiscourse in argumentative writing by Malaysian tertiary level of students. English Language Teaching, 6(9), 83.

Crismore, A., Markkanen, R., \& Steffensen, M. S. (1993). Metadiscourse in persuasive writing: A study of texts written by American and Finnish university students. Written communication, 10 (1), 39-71.

Geng, Y., \& Wharton, S. (2016). Evaluative language in discussion sections of doctoral theses: Similarities and differences between L1 Chinese and L1 English writers. Journal of English for Academic Purposes, 22, 80-91.

Gholami, J., Nejad, S. R., \& Pour, J. L. (2014). Metadiscourse Markers Misuses; a Study of EFL Learners' Argumentative Essays. Procedia-Social and Behavioral Sciences, 98, 580-589.

Hyland, K. (1998). Persuasion and context: The pragmatics of academic metadiscourse. Journal of pragmatics, 30(4), 437-455.

Hyland, K. (2003). Genre-based pedagogies: A social response to process. Journal of second language writing, 12(1), 17-29.

Hyland, K., \& Tse, P. (2004). Metadiscourse in academic writing: A reappraisal. Applied linguistics, 25(2), 156-177.

Hyland, K. (2004). Disciplinary interactions: Metadiscourse in L2 postgraduate writing. Journal of second language writing, 13(2), 133-151.

Hyland, K. (2005). Metadiscourse: Exploring writing in interaction. London: Continuum, 13-15.

Hyland, K. (2005). Stance and engagement: A model of interaction in academic discourse. Discourse studies, 7(2), 173-192.

Hidayati, F., Muhammad, A., \& Dallyono, R. (2008). The use of hedging in academic discourse. Educationists, 2(1), 27-37. 
290 Celt: A Journal of Culture, English Language Teaching \& Literature, Volume 17, Number 2, December 2017, pp. 270 - 291

Intaraprawat, P., \& Steffensen, M. S. (1995). The use of metadiscourse in good and poor ESL essays. Journal of second language writing, 4(3), 253 272 .

Khedri, M., Ebrahimi, S. J., \& Heng, C. S. (2013). Interactional metadiscourse markers in academic research article result and discussion sections. 3L: Language, Linguistics, Literature $\AA, 19(1)$.

Letsoela, P. M. (2014). Interacting with Readers: Metadiscourse Features in National University of Lesotho Undergraduate Students' Academic Writing. International Journal of Linguistics, 5(6), 138-153.

Allami, H. (2013). Metadiscourse markers in the discussion/conclusion section of Persian and English master's theses. Journal of Teaching Language Skills, 32(3), 23-40.

Nasiri, S. (2013). Exploring the significant role of meta-discourse in academic writing for a discourse community by academic members. International Journal of Research Studies in Education, 2(1), 67-74.

Pope, G. (2011). First, Second and Third Person. Available at www. quickanddirtytips.com.

Salichah, I., Irawati, E., \& Basthomi, Y. (2015). Hedges and Boosters in Undergraduate Students' Research Articles. Jurnal Pendidikan Humaniora, 3(2), 154-160.

Sanford, S. G. (2012). A comparison of metadiscourse markers and writing quality in adolescent written narratives (Doctoral Dissertation). The University of Montana).

Simin, S., \& Tavangar, M. (2009). Metadiscourse knowledge and use in Iranian EFL writing. The Asian EFL Journal Quarterly, 11(1), 230-255.

Swales, J. (1990). Genre analysis: English in academic and research settings. Cambridge University Press.

Swales, J. M. (2000). English in today's research world: A writing guide. University of Michigan, Ann Arbor, MI (EUA).

Swetnam, D. (2004). Writing Your Dissertation: How to Plan, Prepare and Present Successful Work. Oxford: How to Book Ltd. 
Susanti, Y., Kurnia, F.D., \& Suharsono, Interactional Metadiscourse Markers 291 in the Introduction of Dissertations: Differences across English Proficiency Level

Takimoto, M. (2015). A Corpus-Based Analysis of Hedges and Boosters in English Academic Articles. Indonesian Journal of Applied Linguistics, 5(1), 95-105.

Wallwork, A. (2011). English for Writing Research Paper. London: Spinger Sccience-Business Media.

Williams, J. (1981), Style: Ten Lessons in Clarity and Grace. Boston: Scott Foresman. 